\title{
Low cost nanoparticles derived from nitrogen fertilizer industry waste for the remediation of copper contaminated soil and water
}

\author{
Elsayed Elkhatib $^{1^{\dagger}}$, Mohamed Moharem ${ }^{2}$, Ayman Mahmoud ${ }^{3}$ \\ ${ }^{1}$ Department of Soil and Water Sciences, Alexandria University, Alexandria, Egypt \\ ${ }^{2}$ Regional Center for Food and Feed, Agricultural Research Center, Alexandria, Egypt \\ ${ }^{3}$ Alexandria Fertilizers Company, Alexandria, Egypt
}

\begin{abstract}
The goal of this study was to produce a novel nano-scale material from nitrogen fertilizer industry byproduct (nNFIB) and assess its capability to remediate $\mathrm{Cu}$ contaminated wastewater and soil. The novel nNFIB was produced using planetary mono mill and characterized. Equilibrium and kinetics studies of $\mathrm{Cu}$ sorption by nNFIB were performed in batch system. The effects of a variety of factors, including $\mathrm{pH}$, coexisting ions and adsorption time on $\mathrm{Cu}$ adsorption were investigated. Furthermore, $\mathrm{Cu}$ sequestration mechanism onto nNFIB was investigated using sequential extraction technique and Fourier transform infrared (FTIR) spectra before and after nNFIB adsorption. The Cu sorption equilibrium and kinetics data were successfully described by Langmuir and first-order models, respectively. The calculated maximum $\mathrm{Cu}$ (II) adsorption capacity (qmax) of nNFIB (100 mg g-1) was four times higher than qmax of bulk NFIB. Copper removal by nNFIB was quite fast (around $86 \%$ ) in the first 5 min and gradually slowed down until achieved $100 \%$ removal at equilibrium time. The FTIR spectra and $\mathrm{Cu}$ fractionation data in biosolid-amended soil demonstrated that $\mathrm{Cu}$ sequestration in contaminated water and soil is strongly related to $\mathrm{CaCO}_{3}$ of $\mathrm{nNFIB}$. The overall findings show the potential use of $\mathrm{nNFIB}$ as a best management practice for $\mathrm{Cu}$ removal from wastewater and $\mathrm{Cu}$ stabilization in contaminated biosolid-amended soils.
\end{abstract}

Keywords: Biosolid-amended sandy soil, $\mathrm{Cu}$ fractionation, $\mathrm{Cu}$ sequestration, FTIR spectra, Sorption and kinetic models, Wastewater

\section{Introduction}

Anthropogenic activities have polluted the environment with excess amounts of heavy metals. Rapid industrialization and urbanization have discharged huge amounts of heavy metals into ecosystems and metals such as copper are introduced mainly by electroplating and metal mining industries and water pipe work [1]. Because copper is very toxic at low concentration, copper-contaminated wastewater must be treated before discharging to protect the environment. Exposure to excessive amounts of copper can cause serious health problems because of its bio-accumulation and high toxicity [2, 3]. United State Environmental Protection Agency (USEPA) reported that the permissible limit of copper ions in industrial effluents is $1.3 \mathrm{mg} / \mathrm{L}$ while World Health Organization (WHO) stated that copper ions content in drinking water should not exceed $1 \mathrm{mg} / \mathrm{L}[4,5]$. Therefore, the development of low-cost,

This is an Open Access article distributed under the term of the Creative Commons Attribution Non-Commercial License (http://creativecommons.org/licenses/by-nc/3.0/) which permits unrestricted non-commercial use, distribution, and reproduction in any medium, provided the original work is properly cited.

Copyright (C) 2020 Korean Society of Environmental Engineers yet efficient and environment-friendly technologies to remediate $\mathrm{Cu}$ contaminated water and soil is urgent to protect and preserve public and ecosystem health.

Remediation of $\mathrm{Cu}$ contaminated water and soil can be performed by different technologies including chemical/electro-chemical processes, ion exchange, reverse osmosis, coagulation, and adsorption [6, 7].The removal of metal ions better accomplished by adsorption due to its safety, simplicity and the advancement of adsorption technology. However, the newly introduced adsorbents such as active carbon, graphene oxide and mesoporous silica are economically unattractive [8].

In recent years, sustainable resources have become a greater concern and research has focused on the production of low cost sorbents from industrial byproducts such as egghells, oyster shells, water treatment residuals, Fly ash and iron slags and the ability of these byproducts to remove aqueous pollutants have also been

Received December 17, 2018 Accepted December 26, 2019

${ }^{\dagger}$ Corresponding author

Email: selkhatib1@yahoo.com

Tel: +2-035-904-684 Fax: +2-035-904-684

Orchid: 0000-0002-0962-9230 
tested [9-11]. There is a wealth of recent articles regarding industrial and agricultural byproducts as a precursor [12]. However, information is lacking on sorbents produced from calcite-based waste materials generated from nitrogen fertilizer industry as a precursor materials and the feasibility of using it in water and soil remediation. Worldwide, millions of tons of calcite-based solid waste from nitrogen fertilizer industry are generated each year. Surprisingly, no information or systematic study regarding the use of NFIB for $\mathrm{Cu}^{2+}$ removal has been reported. Thus, the overall purpose of this work is to determine the ability of calcite-based materials generated from nitrogen fertilizer industry byproducts to remediate contaminated soil and water.

The specific objectives of the current study were to: (1) produce and characterize a novel nanomaterials derived from nNFIB and examine the feasibility of using such materials as simple yet effective adsorbents for aqueous copper removal and immobilization (2) optimize the various parameters governing $\mathrm{Cu}^{2+}$ removal such as $\mathrm{pH}$, contact time, and coexisting ions (3) investigate $\mathrm{Cu}$ sequestration mechanism onto nNFIB. For the best of authors' knowledge there are no other articles in existence concerning the use of nanoparticles derived from nitrogen fertilizers industry byproducts for remediation of copper contaminated soil and water.

\section{Material and Methods}

\subsection{Preparation and Characterization of $\mathrm{nNFIB}$}

The NFIB was obtained from nitrogen fertilizer company, Alexandria, Egypt. The NFIB samples were collected, air-dried, ground and passed through two different sieves having pore diameters of $2 \mathrm{~mm}$ (mNFIB) and $51 \mu \mathrm{m}(\mu \mathrm{NFIB})$. Nanoparticles of NFIB were produced using subsamples of $\mu \mathrm{NFIB}(<51 \mu \mathrm{m})$ and Planetary Mono Mill according to the method of Elkhatib et al. [13]. The crystalline nature of nNFIB was determined using Bruker AXS D8 Advance X-ray Diffractometer. The particles size, morphology and elemental composition of nNFIB were investigated using scanning electron microscope equipped with energy dispersive spectroscopy (SEM-EDS) (INCAx-Sight, Oxford Instruments, UK). Surface area of nNFIB was determined using autosorb iQ surface area analyzer (Quanta chrome, USA).

\subsection{Sorption Isotherms and Kinetics}

Copper (II) sorption equilibrium studies were performed on $\mathrm{mNFIB}$ and $\mathrm{nNFIB}$ at normal $\mathrm{pH}$ (7.2) using $0.01 \mathrm{M} \mathrm{KNO}_{3}$ and $\mathrm{Cu}$ (II) concentrations ranging from $10-500 \mathrm{mg} / \mathrm{L}$. The NFIB-Cu mixtures (in replicate) were equilibrated on a shaker for $24 \mathrm{~h}$, centrifuged for 10 $\mathrm{min}$ at $4000 \mathrm{rpm}$, filtered through a membrane filter $(0.45 \mu \mathrm{m})$ and the filtrate was analyzed for $\mathrm{Cu}$ by Atomic absorption spectroscopy(AAS). Seven sorption isotherm models were assessed for their ability to fit the sorption data [14]. The sorbed $\mathrm{Cu}$ by nNFIB was examined via SEM equipped with an EDS (INCAx-Sightmodel 6587, Oxford Instruments, UK).

Batch sorption kinetic experiments were conducted with $\mathrm{Cu}$ at room temperature $\left(25 \pm 2^{\circ} \mathrm{C}\right)$. A known dose of nNFIB (150 $\mathrm{mg}$ ) was mixed with $20 \mathrm{~mL}$ of $\mathrm{Cu}$ (II) solutions with initial concentration of $500 \mathrm{mg} / \mathrm{L}$ in $50 \mathrm{~mL}$ centrifuge tubes. The mixtures (in replicate) were shaken for different time intervals (5 min - $24 \mathrm{~h}$ ) using an end-over-end shaker at 3 different $\mathrm{pH}$ levels $(\mathrm{pH} \mathrm{5,} 7$ and 9). The $\mathrm{pH}$ was kept constant by automatic titration with $\mathrm{HCl}$ or $\mathrm{NaOH}$. The $\mathrm{Cu}-\mathrm{nNFIB}$ suspensions were centrifuged and then filtered using $0.45 \mu \mathrm{m}$ Milliporefilter. Atomic absorption spectrometry (AAS, contrAA300) was used to analyze $\mathrm{Cu}$ (II) concentrations in the supernatant solutions. Stock standard $\mathrm{Cu}\left(\mathrm{NO}_{3}\right)_{2}$ solution (1000 $\mathrm{mgL}^{-1}$ ) was used to prepare $\mathrm{Cu}(\mathrm{II})$ solutions. The kinetics of $\mathrm{Cu}$ sorption on the nNFIB samples were investigated by fitting the sorption data to power function, parabolic diffusion, first order, and Elovich kinetic models [9].

\subsection{Spiking Biosolids and Incubation Experiment}

Biosolids samples originally contained $12.80 \mathrm{mg} \mathrm{Cu} \mathrm{kg}{ }^{-1}$ were collected and spiked with $\mathrm{Cu}$ nitrate at a rate of $300 \mathrm{mg} \mathrm{Cu} \mathrm{kg}^{-1}$, the soil $\mathrm{Cu}$ concentration limit recommended by the USDA [15]. The Cu-spiked biosolids samples were incubated under aerobic conditions at room temperature $\left(25 \pm 2^{\circ} \mathrm{C}\right)$ and $70 \%$ water holding capacity for $30 \mathrm{~d}$ and then were mixed with $2 \mathrm{~kg}$ of sandy soil. Four different rates of nNFIB $(0,0.25,0.5$, and $1 \%)$ were added to soil -biosolids mixtures, placed in plastic bags, and incubated for $20 \mathrm{~d}$ at room temperature $\left(25 \pm 2^{\circ} \mathrm{C}\right)$. During the incubation period, moisture content of the mixtures was maintained at $70 \%$ of water holding capacity (WHC).

\subsection{Copper Fractionation}

The procedure of Tessier et al. [16] was used to fractionate $\mathrm{Cu}$ in soil-biosolids mixtures before and after application of $\mathrm{nNFIB}$. The used procedure fractionates $\mathrm{Cu}$ into five fractions: Exchangeable (Exch), carbonates (Carb), Fe-Mn oxides (FeMnO), organic matter (OM) and Residual (Res). Copper in the fractions was determined using AAS, contr AA300.

\subsection{Statistical Analysis}

The experimental data were statistically analyzed using Microsoft Excel and COSTAT programs Fisher's least significant difference at level of significance $\mathrm{P} \leq 0.01$ was used to separate differences among the treatment means [17].

\section{Results and Discussions}

\subsection{Characterization of Nanoparticles From nNFIB}

The XRD patterns of bulk NFIB and nanoscale NFIB (Fig. S1) demonstrate a strong characteristic peak at $2 \theta=30^{\circ}$ indicating that both samples are mainly containing high percentage (93\%) of calcite $\left(\mathrm{CaCO}_{3}\right)$. The SEM and EDX analyses of both samples confirmed $\mathrm{XRD}$ results and ascertained that the main component of bulk and nanoscale NFIB is calcite (Fig. 1(a), (b)). The SEM image of nNFIB sample before Cu saturation (Fig. 1(b)) showed the spherical shape of nanoparticles and the representative single particle sizes( $<100 \mathrm{~nm}$ ) in diameter. The SEM image of Cu saturated nNFIB, also revealed that adsorbed $\mathrm{Cu}$ has formed a coating layer on $\mathrm{nNFIB}$ surface (Fig. 1(c)) and the presence of $\mathrm{Cu}$ peak $(3.70 \% \pm 0.76)$ has been confirmed by EDX spectrum of Cu saturated nNFIB (Fig. 

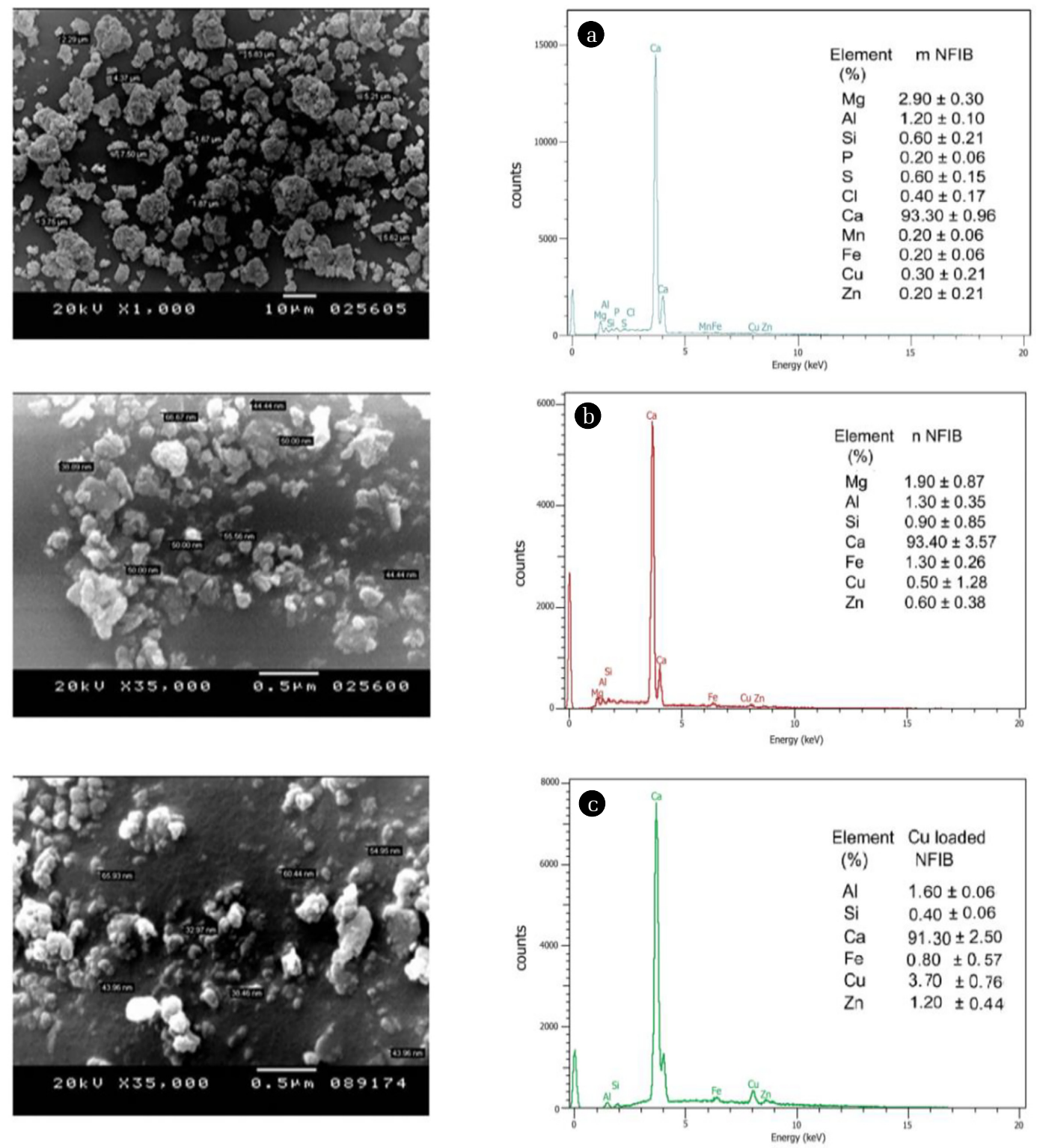

Fig. 1. Scanning electron microscopy (SEM) image and energy dispersive X-ray (EDX) elemental distribution of (a) mNFIB, (b) nNFIB and (c) the Cu-loaded nNFIB.

1(c)) .Meanwhile, EDX analysis showed a decrease in calcium percentage from 93.4 to $91.3 \%$ of the total elements in nNFIB as a result of $\mathrm{Cu}$ ions addition (Fig. 1(b), (c)).

\subsection{Sorption Isotherm}

Sorption isotherm studies were performed to determine the maximum sorption capacity for the three different particle sizes of NFIB (m NFIB, $\mu$ NFIB and $n$ NFIB). Copper sorption isotherms (Fig. 2(a)) have shown continuous increase of sorbed $\mathrm{Cu}$ by nNFIB, uNFIB and mNFIB with increasing $\mathrm{Cu}$ concentration from 5 to $500 \mathrm{mg} \mathrm{L}^{-1}$. The $\mathrm{Cu}$ adsorption capacity of $\mathrm{nNFIB}$ was higher than that of uNFIB and mNFIB. Reliable prediction of $\mathrm{Cu}$ adsorption parameters including maximum sorption capacity was further ana- lyzed using 7 sorption isotherms models [13, 18] (Table 1). Langmuir and Temkin models best described $\mathrm{Cu}$ sorption data in the order: Langmuir > Temkin as evidenced by the high determination coefficient $\left(R^{2}\right)$ and low standard error of estimate (SE) values of these models (Table 1) .

The superiority of Langmuir model to describe the adsorption behavior of $\mathrm{Cu}$ (II) on nNFIB, uNFIB and mNFIB (Fig. 2(b), Table 1) indicates the involvement of monolayer adsorption in the $\mathrm{Cu}$ (II) removal process by nNFIB,uNFIB and mNFIB. Based on Langmuir model, the calculated maximum $\mathrm{Cu}$ (II) adsorption capacity ( $\mathrm{q}_{\max }$ ) of nNFIB is $100 \mathrm{mg} \mathrm{g}^{-1}$ which is four times higher than that of Bulk NFIB. This is not surprising since the BET specific surface area of nNFIB $\left(225.4 \mathrm{~m}^{2} \mathrm{~g}^{-1}\right)$ is much higher than that of the bulk 
Table 1. Equilibrium Model Constants and Standard Error of Estimate (SE) and Determination Coefficients $\left(\mathrm{R}^{2}\right)$ for Copper Adsorption by the Three Different Particles Sizes of NFIB

\begin{tabular}{|c|c|c|c|c|}
\hline Models & Parameter & m NFIB & $\mu$ NFIB & n NFIB \\
\hline & $\mathrm{K}_{\mathrm{F}}\left(\mathrm{mL} \mathrm{\textrm {g } ^ { - 1 }}\right)$ & $5.009 \times 10^{3}$ & $5.519 \times 10^{3}$ & $8.119 \times 10^{3}$ \\
\hline Freundlich & $1 / \mathrm{n}$ & 0.255 & 0.294 & 0.413 \\
\hline \multirow[t]{3}{*}{$\mathrm{q}_{\mathrm{e}}=\mathrm{K}_{\mathrm{F}} \mathrm{C}_{\mathrm{e}}^{1 / \mathrm{n}}$} & $\mathrm{R}^{2}$ & 0.49 & 0.62 & 0.78 \\
\hline & SE & 0.98 & 0.88 & 0.78 \\
\hline & $\mathrm{q}_{\max }\left(\mu \mathrm{gg}^{1}\right)$ & 25000 & 30000 & 100000 \\
\hline Langmuir & $\mathrm{K}_{\mathrm{L}}\left(\mathrm{L} \mathrm{mg}^{-1}\right)$ & 0.25 & 0.29 & 0.33 \\
\hline \multirow[t]{3}{*}{$\mathrm{q}_{\mathrm{e}}=\mathrm{q}_{\max }\left(\mathrm{K}_{\mathrm{L}} \mathrm{C}_{\mathrm{e}} / 1+\mathrm{K}_{\mathrm{L}} \mathrm{C}_{\mathrm{e}}\right)$} & $\mathrm{R}^{2}$ & 0.99 & 0.96 & 0.94 \\
\hline & SE & $7.4 \times 10^{-5}$ & $6.69 \times 10^{-5}$ & $1.36 \times 10^{-5}$ \\
\hline & $\mathrm{q}_{\max }\left(\mu \mathrm{gg}^{1}\right)$ & $1.67 \times 10^{4}$ & $2.00 \times 10^{4}$ & $2.50 \times 10^{4}$ \\
\hline Elovich & $\mathrm{K}_{\mathrm{E}}\left(\mathrm{L} \mathrm{mg}^{-1}\right)$ & 1.647 & 1.135 & 1.341 \\
\hline \multirow[t]{2}{*}{$\mathrm{q}_{\mathrm{e}} / \mathrm{q}_{\max }=\mathrm{K}_{\mathrm{E}} \mathrm{C}_{\mathrm{e}} \exp \left(-\mathrm{q}_{\mathrm{e}} / \mathrm{q}_{\max }\right)$} & $\mathrm{R}^{2}$ & 0.25 & 0.49 & 0.50 \\
\hline & SE & 0.463 & 0.329 & 0.412 \\
\hline \multirow{4}{*}{$\begin{array}{l}\text { Temkin } \\
\theta=\mathrm{RT} / \Delta \mathrm{Q} \ln K_{0} \mathrm{C}_{\mathrm{e}}\end{array}$} & $\Delta \mathrm{Q}\left(\mathrm{k} \mathrm{J} \mathrm{mol}{ }^{-1}\right)$ & 6.275 & 9.044 & 26.313 \\
\hline & $\mathrm{K} 0\left(\mathrm{~L} \mathrm{~g}^{-1}\right)$ & 20.337 & 24.062 & 28.838 \\
\hline & $\mathrm{R}^{2}$ & 0.98 & 0.97 & 0.98 \\
\hline & SE & 0.116 & 0.106 & 0.051 \\
\hline \multirow{4}{*}{$\begin{array}{l}\text { Fowler-Guggenheim(FG) } \\
\mathrm{K}_{\mathrm{FG}} \mathrm{C}_{\mathrm{e}}=\theta / 1-\theta \exp (2 \theta \mathrm{w} / \mathrm{RT})\end{array}$} & $\mathrm{W}\left(\mathrm{kJ} \mathrm{mol}^{-1}\right)$ & -3.221 & -0.680 & 5.134 \\
\hline & $\mathrm{K}_{\mathrm{FG}}\left(\mathrm{L} \mathrm{mg}^{-1}\right)$ & 1.467 & 2.228 & 0.718 \\
\hline & $\mathrm{R}^{2}$ & 0.94 & 0.80 & 0.97 \\
\hline & SE & 0.221 & 0.109 & 0.348 \\
\hline \multirow{4}{*}{$\begin{array}{l}\text { Kiselev } \\
\mathrm{k}_{1} \mathrm{C}_{\mathrm{e}}=\theta /(1-\theta)\left(1+\mathrm{k}_{\mathrm{n}} \theta\right)\end{array}$} & $\mathrm{k}_{1}\left(\mathrm{~L} \mathrm{mg}^{-1}\right)$ & 1.476 & 1.449 & 0.489 \\
\hline & $\mathrm{kn}$ & 1.913 & 1.034 & 2.570 \\
\hline & $\mathrm{R}^{2}$ & 0.80 & 0.95 & 0.97 \\
\hline & SE & 5.122 & 3.012 & 2.679 \\
\hline \multirow{4}{*}{$\begin{array}{l}\text { Hill-deBoer } \\
\mathrm{K}_{1} \mathrm{C}_{\mathrm{e}}=\theta /(1-\theta) \exp \left(\theta /(1-\theta)-\mathrm{K}_{2} \theta / \mathrm{RT}\right)\end{array}$} & $\mathrm{K}_{1}\left(\mathrm{Lmg}^{-1}\right)$ & 1.270 & 1.077 & 0.498 \\
\hline & $\mathrm{K}_{2}\left(\mathrm{~kJ} \mathrm{~mol}^{-1}\right)$ & 12.164 & 12.717 & 3.704 \\
\hline & $\mathrm{R}^{2}$ & 0.99 & 0.98 & 0.94 \\
\hline & SE & 0.088 & 0.249 & 0.132 \\
\hline
\end{tabular}

$\mathrm{q}_{\mathrm{e}}\left(\mathrm{mg} \mathrm{g}^{-1}\right)$ is $\mathrm{Cu}$ adsorbed per gram of adsorbent, $\mathrm{C}_{\mathrm{e}}\left(\mathrm{mg} \mathrm{L}^{-1}\right)$ is equilibrium $\mathrm{Cu}$ concentration in solution, $\mathrm{K}_{\mathrm{f}}$ is a constant related to adsorption capacity of the adsorbent $\left(\mathrm{Lmg}^{-1}\right), \mathrm{n}$ is a constant, $\mathrm{q}_{\max }\left(\mathrm{mg} \mathrm{g}^{-1}\right)$ is the maximum adsorption capacity of the adsorbent, $\mathrm{K}_{\mathrm{L}}\left(\mathrm{Lmg}^{-1}\right)$ is Langmuir constant related to the free energy of adsorption, $\theta$ is fractional coverage, $\mathrm{R}$ is the universal gas constant $\left(\mathrm{kJ} \mathrm{mol}^{-1} \mathrm{~K}^{-1}\right), \mathrm{T}$ is the temperature $(\mathrm{K}), \Delta \mathrm{Q}$ is $(-\Delta \mathrm{H})$ the variation of adsorption energy ( $\mathrm{kJmol}^{-1}$ ), $\mathrm{K}_{0}$ is Temkin constant $\left(\mathrm{Lmg}^{-1}\right.$ ), $\mathrm{K}_{\mathrm{FG}}$ is Fowler-Guggenheim constant $\left(\mathrm{Lmg}^{-1}\right), \mathrm{W}$ is the interaction energy between adsorbed molecules $\left(\mathrm{kJmol}^{-1}\right), \mathrm{K}_{1}$ is Kiselev constant $\left(\mathrm{Lmg}^{-1}\right), \mathrm{K}_{\mathrm{n}}$ is a constant of complex formation between adsorbed molecules, $\mathrm{K}_{1}$ is Hill-de Boer constant $\left(\mathrm{Lmg}^{-1}\right)$, and $\mathrm{K}_{2}\left(\mathrm{kJmol}{ }^{-1}\right)$ is a constant related to the interaction between adsorbed molecules. A positive $K_{2}$ means attraction between adsorbed species and a negative value means repulsion.
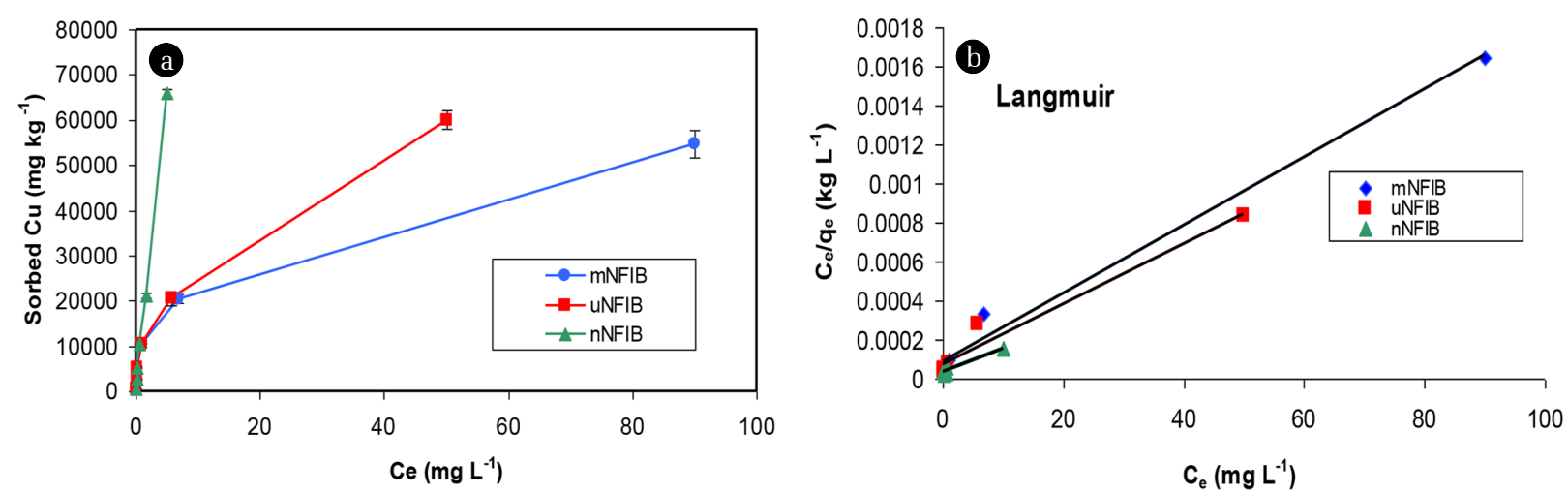

Fig. 2. (a) Copper sorption isotherm onto mNFIB, uNFIB and $n$ NFIB materials. (b) Langmuir sorption isotherms. 

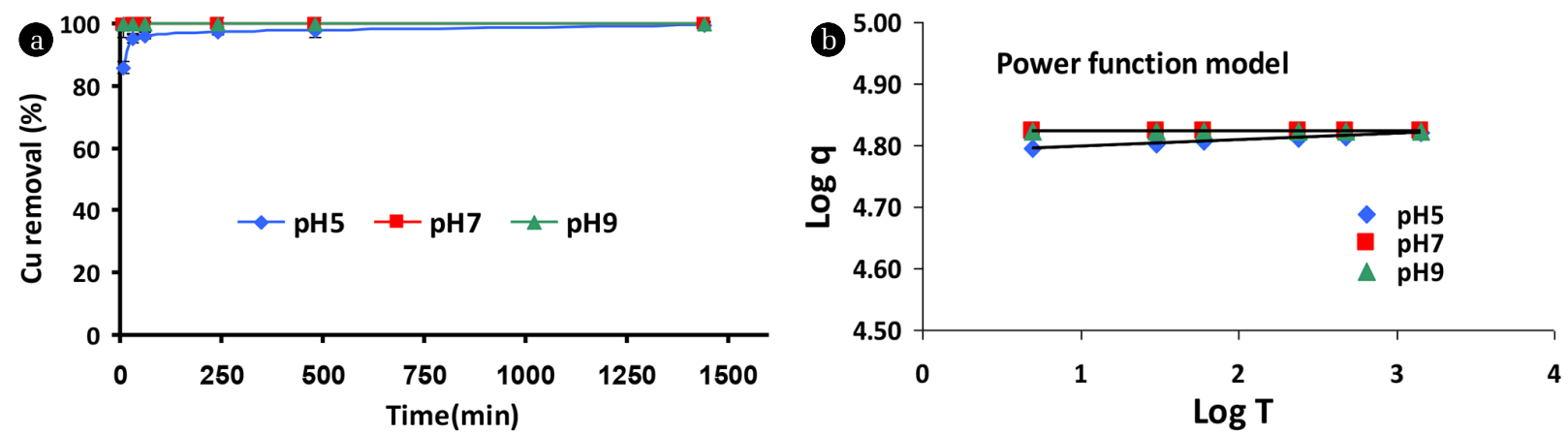

Fig. 3. (a) Effect of contact time on the removal of $\mathrm{Cu}$ (II) by nNFIB at 3 different $\mathrm{pH}$ values, (b) Power function model for Cu (II) adsorption by $\mathrm{nNFIB}$.

NFIB sample $\left(8.8 \mathrm{~m}^{2} \mathrm{~g}^{-1}\right)$. High surface area of nanoparticles greatly enhances surface reactivity and the adsorption capacity of nNFIB [17].Therefore, producing NFIB in nanoscale will greatly enhance its capability to remove $\mathrm{Cu}$ (II) from contaminated wastewater.

\subsection{Effect of Adsorbent-Sorbate Contact Time}

The effects of contact time ( 5 min to $24 \mathrm{~h}$ ) on $\mathrm{Cu}$ (II) adsorption by nNFIB at three different $\mathrm{pH}$ values $(5,7$, and 9 ) are presented in Fig. 3(a). Over $86 \%$ of $\mathrm{Cu}$ (II) was removed by nNFIB in the first $5 \mathrm{~min}$ and then slowed down to reach 100\% removal at the end of the $24 \mathrm{~h}$ (equilibrium time). The fast $\mathrm{Cu}$ removal is attributed to the high proportion of calcium carbonate (more 93\%) in nNFIB and with time the availability of adsorption active sites rendered non available. Increasing the initial $\mathrm{pH}$ of aqueous solutions from 5 to 9 increased the removal efficiency of $\mathrm{Cu}$ (II) by nNFIB (Fig. $3)$. With increasing $\mathrm{pH}$ values $(\mathrm{pH}>7)$, the surface charges of nNFIB became more negative and that may cause a greater ion-exchange reaction between $\mathrm{Cu}$ (II) and $\mathrm{Ca}(\mathrm{II})$ and greater sequestration of $\mathrm{Cu}(\mathrm{II})$ at the nNFIB surface [19]. These results are also supported by other researchers [20, 21].

Copper adsorption data at three $\mathrm{pH}$ values (5, 7, and 9) were kinetically analyzed and fitted to Elovich, first-order, Parabolic diffusion, and power function models [22, 23] (Table S1). The power function and first-order kinetics models best described copper (II) adsorption on nNFIB in the order: power function model $>$ first-order as evidenced by their highest $\mathrm{R}^{2}$ and lowest $\mathrm{SE}$ values (Table S1, Fig. 3). The adsorption rate $\left(\mathrm{K}_{\mathrm{a}}\right)$ of the power function model increased from $5.71 \times 10^{4}$ to $6.70 \times 10^{4} \mathrm{~min}^{-1}$ with the increase in the system $\mathrm{pH}$ from 5 to 9 (Table S1) which indicates that $\mathrm{Cu}$ sorption is preferably at high $\mathrm{pH}$ values.

\subsection{Mechanism of Copper (II) Removal by nNFIB}

The FTIR Spectra of nNFIB was generated in the frequency range $350-4400 \mathrm{~cm}^{-1}$ before and after copper adsorption to elucidate $\mathrm{Cu}$ (II) adsorption mechanism (Fig. 4). The broad band at 3451 $\mathrm{cm}^{-1}$ in the FTIR spectrum of nNFIB is assigned to the OH stretching vibrations of the hydroxyl molecule [24]. The vibration bands at $1439 \mathrm{~cm}^{-1}, 875 \mathrm{~cm}^{-1}, 712 \mathrm{~cm}^{-1}$ and $409 \mathrm{~cm}^{-1}$ indicate plane bending vibration of carbonate [25-29]. After $\mathrm{Cu}$ (II) adsorption by nNFIB, the band at $3451 \mathrm{~cm}^{-1}$ was decreased in the intensity and shifted to lower wave number $\left(3437 \mathrm{~cm}^{-1}\right)$. In addition, the intensities

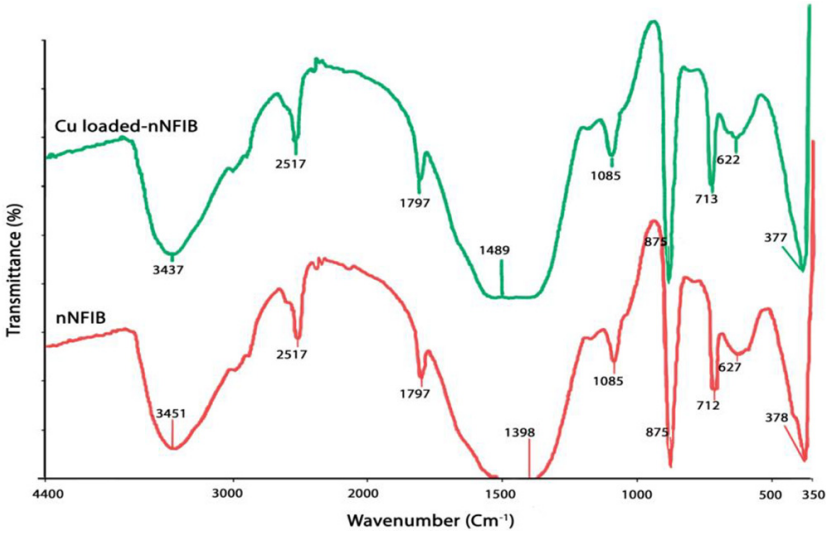

Fig. 4. Fourier transmission infrared (FTIR) spectra of nNFIB and Cu-loaded (II) $\mathrm{nNFIB}$.

of the bands corresponded to amorphous calcium carbonate at 875 and $712 \mathrm{~cm}^{-1}$ clearly increased and the $\mathrm{CO}_{3}^{-}$symmetric stretch at $1398 \mathrm{~cm}^{-1}$ shifted to $1439 \mathrm{~cm}^{-1}$. These shifts are typical for $\mathrm{Cu}^{2+}$ complexation by $\mathrm{OH}$ group and precipitation as copper(II) carbonate. Therefore, FTIR analysis demonstrated the involvement of $\mathrm{OH}$ and $\mathrm{CO}_{3}{ }^{--}$groups in $\mathrm{Cu}$ retention by nNFIB and suggested that $\mathrm{Cu}$ (II) adsorption by $\mathrm{nNFIB}$ at high $\mathrm{pH}(>7)$ may take place via $\mathrm{OH}$ bonding colloidal insoluble hydroxides, $\mathrm{Cu}(\mathrm{OH})_{2}$ and surface precipitation as copper(II) carbonate.

\subsection{Copper Removal in Single and Multi-Element System by $\mathrm{nNFIB}$}

The effect of coexisting ions on $\mathrm{Cu}$ removal by nNFIB was studied by using two competing cations ( $\mathrm{Cd}$ and $\mathrm{Pb}$ ) at concentrations equal to $\mathrm{Cu}$ concentration. Copper removal by nNFIB was markedly affected by the presence of $\mathrm{Cd}$ (II) and $\mathrm{Pb}$ (II) at160 $\mathrm{mgL}^{-1}$ concentration (Fig. 5). The $\mathrm{Cu}$ removal efficiency of nNFIB decreased by $17.6 \%$ (from $98.6 \%$ to $81.0 \%$ ), $5.0 \%$ (from $98.8 \%$ to 93.8 ), $6.1 \%$ (from $99.2 \%$ to $93.1 \%$ ), and $4.9 \%$ (from $99.5 \%$ to 94.6 ) at $\mathrm{Cu}$ concentrations 5, 20, 40 and $80 \mathrm{mgL}^{-1}$, respectively. The competitive effect of Cd (II) and $\mathrm{Pb}$ (II) for the adsorption sites available to $\mathrm{Cu}$ (II) may attributed to some properties of the metal ion such as : (1) electro-negativity, (2) charge to radius ratio, (3) abilities to form hydroxo complexes, and (4) preferred adsorption site on the adsorbent [30-32]. 


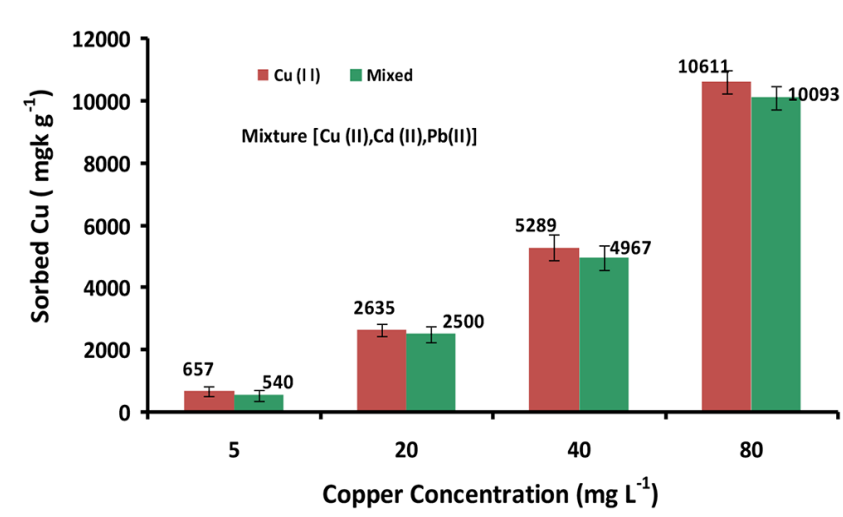

Fig. 5. Removal of copper (II) in single and multi-element system by nNFIB.

\subsection{Effect of nNFIB Application on Cu (II) Sequestration in Contaminated Soil}

The effect of $\mathrm{nNFIB}$ application on distribution of $\mathrm{Cu}$ fractions in contaminated biosolids amended soil is presented in Fig. 6. The percentages of copper fractions in NNFIB unamended soil followed the order: Res $>$ FeMnO $>$ OM $>$ Exch $>$ Carb. Application of nNFIB to the contaminated biosolids amended soil at rates of $0.25,0.50$ and $1.0 \%$ greatly reduced the Exch-Cu and Res fractions and simultaneously increased carbonate fractions. In the soil amended with $1.0 \% \mathrm{nNFIB}, \sim 37 \%$ of $\mathrm{Cu}$ (II) was associated with the carbonate fraction, whereas organic (13.66\%), and exchangeable (6.46\%) fractions represent the minor association. nNFIB application significantly increased $\mathrm{Cu}$ association with the carbonate fraction and consequently enhanced $\mathrm{Cu}$ (II) immobilization in the soil studied. Therefore, it is suggested that the use of nNFIB for $\mathrm{Cu}$ sequestration could geochemically stabilize heavy metals in contaminated soils.

To further investigate $\mathrm{Cu}$ sequestration mechanism onto nNFIB treated soil, FTIR spectra of biosolids amended sandy soil before and after nNFIB application were performed. The FTIR spectrum

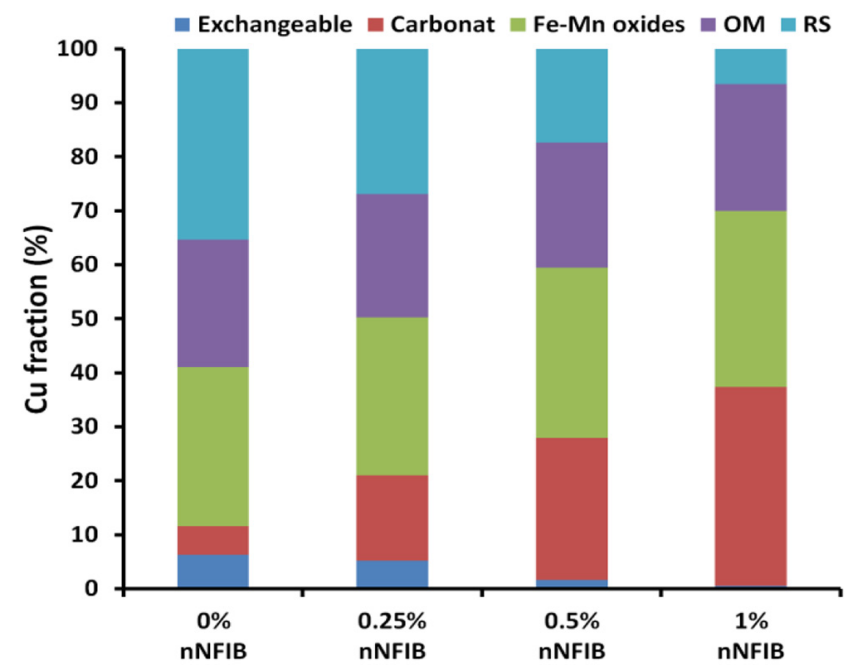

Fig. 6. Percentage of $\mathrm{Cu}$ fractions in biosolids amended soil after nNFIB application at rates of $0,0.25,0.5$, and $1 \%$ by weight.

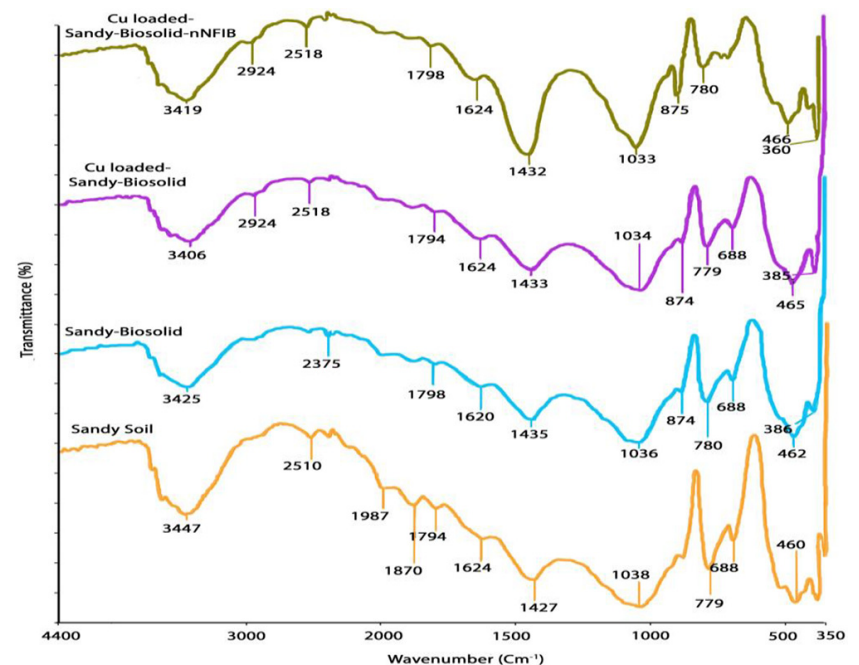

Fig. 7. Fourier transmission infrared (FTIR) spectra of Cu-loaded sandy soil and amended with biosolids before and after nNFIB application.

of the biosolids amended sandy soil (Fig. 7) displays prominent bands at 3406, 1435, 876 and $1033 \mathrm{~cm}^{-1}$ which are attributed to $\mathrm{OH}$ bonded water, stretching and vibration modes of carbonate groups, and Si-O-Si bending vibrations, respectively [20, 28, 34]. Application of nNFIB to biosolids amended sandy soil has resulted in a shift of $\mathrm{OH}$ bonded water band at $3406 \mathrm{~cm}^{-1}$ to a higher wave number $\left(3419 \mathrm{~cm}^{-1}\right)$ and a reduction of its intensity due to the strong interaction between $\mathrm{OH}$ groups and $\mathrm{Cu}$ ions. Meanwhile, the intensity of the band attributed to calcite at $1433 \mathrm{~cm}^{-1}$ greatly increased as a result of increasing $\mathrm{CO}_{3}{ }^{2-}$ content in the nNFIB biosolids amended sandy soil sample due to nNFIB application (Fig. 7). The FTIR results have clearly shown that $\mathrm{OH}$ and $\mathrm{CO}_{3}^{2-}$ groups are the main functional groups responsible for $\mathrm{Cu}$ (II) sorption by nNFIB [35-37].

\section{Conclusions}

A novel nano-structured adsorbent (nNFIB) derived from the low cost waste of nitrogen fertilizer industry was developed. The high surface area of nanoparticles greatly enhanced surface reactivity and $\mathrm{Cu}(\mathrm{II})$ adsorption capacity of nNFIB. The capability of NFIB nanoparticles to remove $\mathrm{Cu}(\mathrm{II})$ reached 4 times higher than that of bulk NFIB. First-order kinetics model was best suited to the kinetics data. Copper adsorption was affected by the $\mathrm{pH}$ of solution and the background ions. FTIR results demonstrated the important rules of hydroxyl and carbonate groups in sequestering $\mathrm{Cu}$ (II) from contaminated soils and water. In brief, it can be stated that $\mathrm{nNFIB}$ is a promising adsorbent to remove $\mathrm{Cu}$ from wastewater and to stabilize $\mathrm{Cu}$ in contaminated biosolid-amended soils.

\section{Acknowledgment}

This work was financially supported by Alexandria University, Vice Deanship of research. 


\section{Author Contributions}

E.E (Professor) provided the intellectual input and the protocols to be followed in the study, wrote the manuscript and lead the overall study (corresponding author). M.M. (Associate Professor) carried out $\mathrm{Cu}$ analyses and assist in calculations, drawings and interpretation. A.M. (Master) conducted all the experiments.

\section{References}

1. Meena AK. Removal of heavy metal ions from aqueous solutions using carbon aerogel as an adsorbent. J. Hazard. Mater. 2005;122:161-170.

2. Lone MI, He Z, Stoffella PJ, Yang X. Phytoremediation of heavy metal polluted soils and water: progresses and perspectives. J. Zhejiang Univ. Sci. B. 2008;9:210-220.

3. Onundi YB, Mamun AA, Al Khatib MF, Ahmed YM. Adsorption of copper, nickel and lead ions from synthetic semiconductor industrial wastewater by palm shell activated carbon. Int. J. Environ. Sci. Tech. 2010;7:751-758.

4. World Health Organization (WHO). Guidelines for drinking-water quality incorporating first addendum to third edition.vol.1. Recommendations. World Health Organization, Geneva, Switzerland; 2006.

5. Aydın H, Bulut Y, Yerlikaya Ç. Removal of copper (II) from aqueous solution by adsorption onto low-cost adsorbents. $J$. Environ. Manag. 2008;87:37-45.

6. Parmar M, Thakur LS. Heavy metal $\mathrm{Cu}, \mathrm{Ni}$ and $\mathrm{Zn}$ toxicity, health hazards and their removal techniques by low cost adsorbents: A short overview. Int. J. Plant Animal Environ. Sci. 2013;3:143-157.

7. Abbas A, Al-amer AM, Laoui T, et al. Heavy metal removal from aqueous solution by advanced carbon nanotubes: Critical review of adsorption applications. Sep. Purif. Technol. 2016;157:141-161.

8. Das R, Vecitis CD, Schulze A, et al. Recent advances in nanomaterials for water protection and monitoring. Chem. Soc. Rev. 2017;46:6946-7020.

9. Elkhatib EA, Mahdy AM, Sherif FK, Elshemy W. Competitive adsorption of cadmium (ii) from aqueous solutions onto nanoparticles of water treatment residual. J. Nanomater. 2016; 2016:1-10.

10. Elkhatib EA, Moharem M, Mahdy AM, Mesalem M. Sorption, release and forms of mercury in contaminated soils stabilized with water treatment residual. Land Degrad. Develop. 2017;28: 752-761.

11. Lim JE, Ahmad M, Lee SS, et al. Effects of lime-based waste materials on immobilization and phytoavailability of cadmium and lead in contaminated soil. Clean Soil Air Water 2013;41:1235-1241.

12. Al-Saydeh SA, El-Naas MH, Zaidi SJ. Copper removal from industrial wastewater: A comprehensive review. J. Industrial Eng. Chem. 2017;56:35-44.

13. Elkhatib EA, Mahdy AM, Salama KA. Green synthesis of water treatment residual nanoparticles using precision milling. Environ. Chem. Lett. 2015;13:333-339.
14. Elkhatib EA, Mahdy AM, Sherif FK, Salama KA. Water treatment residual nanoparticles: a novel sorbent for enhanced phosphorus removal from aqueous medium. Curr. Nanosci. 2015;11: 655-668.

15. USDA.: Urban technical note no. 3. Heavy metal soil contamination. WA. (2000).

16. Tessier A, Campbell PG, Bisson M. Sequential extraction procedure for the speciation of particulate trace metals. Anal. Chem.1979;51:844-851.

17. SAS Institute. SAS/STAT user's guide. Version 9.1 edition. SAS Inst. Inc. Cary, N.C; 2002.

18. Foo KY, and Hameed BH. Insights into the modeling of adsorption isotherm systems. Chem. Eng. J. 2010;156:2-10.

19. Kurniawan TA, Lo WH. Removal of refractory compounds from stabilized landfill leachate using an integrated $\mathrm{H}_{2} \mathrm{O}_{2}$ oxidation and granular activated carbon (GAC) adsorption treatment. Water Res. 2009;43:4079-4091.

20. Ma X, Li L, Yang L, et al. Adsorption of heavy metal ions using hierarchical CaCO3-maltose meso/macroporous hybrid materials: Adsorption isotherms and kinetic studies. J. Hazard. Mater. 2012;209-210:467-477.

21. Wang Y, Tang X, Chen Y, Zhan L, Li Z, Tang Q. Adsorption behavior and mechanism of $\mathrm{Cd}(\mathrm{II})$ on loess soil from China. J. Hazard. Mater. 2009;172:30-37.

22. Song K, Kim, W, Ryu T, Ryu KW, Bang JH, Jang YN. Adsorption of $\mathrm{Cd}(\mathrm{II})$ on waste calcite produced by the carbonation of flue gas desulfurization (FGD) gypsum. Mater. Trans. 2011;52: 224-228.

23. Elkhatib EA, Bennett OL, Wright RJ. Kinetics of arsenite sorption in soils. Soil Sci. Soc. Am. J. 1984;48:758-762.

24. QIU H, LV L, Pan BC, Zhang Q, Zhang W, Zhang QX. Critical review in adsorption kinetic models. J. Zhejiang. Univ. Sci. A. 2009;10:716-724.

25. Parthasarathy G, Unwar A, Srinivasan R. Occurrence of moganite-rich Chalcedony in Deccan flood basalts, Killari, Maharashtra, India. Eur. J. Mineral. 2001;3:127-134.

26. LilkovV, Bechev G, Kolev K. Formation of the structure of the cement stone of well cement with fly-ash microspheres from thermoelectric power station.2. Investigation of the hydration products in the cement stone. Physico - chemical mechanics 1992;21:41-53.

27. Morandat J, Lorenzelli V, Lecomte JI. Détermination expérimentale et essai d'attribution des vi-brations externes actives en infrarouge dans quelques carbonates métalliques a l'état cristallin. J. Physique. 1967;28:152-156.

28. Ma X, Cui W, Yang L, Yang Y, Chen H Wang K. Efficient biosorption of lead(II)and cadmium(II) ions from aqueous solutions by functionalized cell with intracellular CaCO3 mineral scaffolds. Bioresour. Technol. 2015;185:70-78.

29. Lu H, Zhang W, Yang Y, Huang X, Wang S, Qiu R. Relative distribution of $\mathrm{Pb} 2+$ sorption mechanisms by sludge-derived biochar. Water Res. 2012;46:854-862.

30. Hariharan M, Varghese N, Cherian AB, Sreenivasan PV, Paul J, Antony KA. Synthesis and characterisation of $\mathrm{CaCO}_{3}$ (Calcite) nano particles from cockle shells using chitosan as precursor. Inter. J. Sci. Res. Publications 2014;4:1-5.

31. Anna B, Kleopas M, Constantine S, Anestis F, Maria B. 
Adsorption of $\mathrm{Cd}(\mathrm{II}), \mathrm{Cu}(\mathrm{II}), \mathrm{Ni}$ (II) and $\mathrm{Pb}$ (II) onto natural bentonite: study in mono- and multi-metal systems. Environ. Earth Sci. 2015;73:5435-5444.

32. Mohapatra M, Mohapatra L, Singh P, Anand S, Mishra B. A comparative study on $\mathrm{Pb}(\mathrm{II}), \mathrm{Cd}(\mathrm{II}), \mathrm{Cu}(\mathrm{II}), \mathrm{Co}(\mathrm{II})$ adsorption from single and binary aqueous solutions on additive assisted nano-structured goethite. Inter. J. Engin. Sci. Techn. 2010; 2:89-103.

33. Juang RS, Chung JY. Equilibrium sorption of heavy metals and phosphate from single- and binary-sorbate solutions on goethite. J. Colloid. Interface. Sci. 2004;275:53-60.

34. Reig FB, Adelantado VG, Moreno MM. FTIR quantitative analy- sis of calcium carbonate (calcite) and silica (quarts) mixtures using the constant ratio method. Talenta 2002;58:811-821.

35. Cai GB, Zhao GX, Wang XK, Yu SH. Synthesis of polyacrylic acid stabilized amorphous calcium carbonate nanoparticles and their application for removal of toxic heavy metal ions in water. J. Phys. Chem. 2010;114:12948-12954.

36. Zhao X, Jiang T, Du B. Effect of organic matter and calcium carbonate on behaviors of cadmium adsorption-desorption on/from purple paddy soils. Chemosphere 2014;99:41-48.

37. Zuo WQ, Chen C, Cui HJ, Fu ML. Enhanced removal of Cd(II) from aqueous solution using $\mathrm{CaCO}_{3}$ nanoparticle modified sewage sludge biochar. RSC Advances 2017;7:16238-16243. 